\title{
Pertumbuhan Kompensatori Dan Efisiensi Pakan Pada Budidaya Ikan Kakap Putih (Lates calcarifer, Bloch) Melalui Pemuasaan Di Keramba Jaring Apung
}

\section{Compensatory Growth And Feed Efficiency Of Cultured Asian Sea Bass (Lates calcarifer, Bloch) Fasting In Floating Netcage}

\author{
Hendrianto $^{1}$, Meyer Siregar ${ }^{2}$, Sahidan Muhlis $^{3}$ dan Agung Darmono ${ }^{4}$ \\ ${ }^{1234}$ Balai Perikanan Budidaya Laut Batam, Jl. Raya Barelang, Jembatan III, P.Setoko, \\ Batam, Provinsi Kepulauan Riau, Indonesia \\ *Koresponden: hendrianto17@yahoo.com
}

\begin{abstract}
Abstrak
Pakan merupakan komponen terbesar dalam kegiatan budidaya perikanan yang harganya kian meningkat. Manajemen pemberian pakan tanpa menggunakan bahan tambahan/suplemen adalah salah satu upaya efisiensi penggunaan pakan. Diantara inovasi teknologi budidaya yang aplikatif adalah dengan pemuasaan secara periodik. Penelitian mengenai pemuasaan banyak dilakukan tetapi penerapannya dalam skala massal belum banyak dilakukan, khususnya pada kegiatan marikultur. Tujuan kegiatan ini adalah untuk mengetahui dampak pemuasaan secara periodik pada pemeliharaan ikan kakap putih skala produksi di Keramba Jaring Apung (KJA). Parameter pengamatan yakni pertumbuhan, sintasan, rasio konversi pakan, dan efisiensi pakan. Kegiatan kerekayasaan ini dilakukan pada bulan Februari - Agustus 2017 di Balai Perikanan Budidaya Laut Batam Provinsi Kepulauan Riau. Ikan kakap putih berukuran tebar awal 15 - $16 \mathrm{~cm}(48,50-67,15$ gram $)$ sebanyak 1.800 ekor dipelihara di dua jaring dengan kepadatan masing-masing 900 ekor dan perlakuan berbeda. Perlakuan A, ikan uji dengan pemuasaan, lima hari diberi pakan lalu satu hari dipuasakan (5-1), secara periodik berulang hingga akhir pengujian. Perlakuan B, ikan uji diberi pakan setiap hari. Pakan yang diberikan adalah pelet dengan kandungan protein $42 \%$ dengan dosis harian mulai $4 \%$ hingga $2 \%$ sampai akhir pengujian. Hasil pengujian menunjukkan berturut-turut perlakuan A : perlakuan B dari parameter sintasan 91,22\%: 96,11\%; pertumbuhan rerata harian $2,63: 2,68$; rasio konversi pakan $2,29: 2,52$; dan efisiensi pakan $0,44: 0,40$. Dari hitungan produksi, ikan yang dipuasakan dapat menghemat pakan sebesar 15,99\%. Ikan kakap putih dengan pemuasaan menunjukkan adanya pertumbuhan kompensatori dimana dapat memacu pertumbuhannya hingga menyamai bahkan melebihi ikan kontrol. Manajemen pakan melalui pemuasaan secara periodik 5-1 dapat menjadi salah satu solusi untuk efisiensi kegiatan budidaya kakap putih di KJA.
\end{abstract}

Kata kunci: Efisiensi Pakan, Kakap Putih, Pemuasaan, Pertumbuhan Kompensatori

\begin{abstract}
The feed is the hugest factor in aquaculture which promoted of price continuously. Some efforts are done to increase efficiency, such as added of feed additivelfeed supplement that impact to cost production. Another way, is to manage the feeding without feed addictive and others. One of innovative technology in aquaculture is periodically fasting. There were some researches about fasting, but less in applicative in mass production, especially in mariculture. The objective of this applied aquaculture research was to know effect of periodically fasting to cultured Asian Sea Bass in floating netcage. Some parameters obtained are growth, survival rate, feed convertion rate, and feed efficiency. This activity was done in February - August 2017 at Mariculture Development Batam, Riau Islands Province. Asian Sea Bass start sized 15 - 16 cm (48,50 - 67,15 grams) as many as 1.800 fishes cultured in two netcage (density 900 fishes eaches) with difference treatment. Treatment A, fish with five days feeding and then one day fasting (5-1), periodically continous till end. Treatment $B$, fish feeding pellet everyday as control. The feed is pellet for sea bass contained protein $42 \%$ with feeding rate start from $4 \%$ till $2 \%$ to the end. The results shows in succession treatment A : treatment B from parametres survival rate 91,22\%:96,11\%; average daily growth 2,63:2,68; feed convertion rate 2,29:2,52; and feed efficiency $0,44: 0,40$. From the calculation of production, fish with treatment $A$ can save feed by 15,99\%. The fish with feed deprivation and refeeding has compensation growth which increase its growth same as, or even more than the control. Feed management with periodically fasting 5-1 can be applicative solution in efficiency of Asian Sea Bass culture in floating netcage.
\end{abstract}




\section{PENDAHULUAN}

Program pemerintah yakni ketahanan pangan merupakan program yang perlu didukung bersama semua sektor, salah satunya dari perikanan khususnya subsektor perikanan budidaya. Kegiatan budidaya laut membutuhkan banyak komponen yang sangat mempengaruhi keberhasilan usaha, yaitu: ketersediaan benih unggul, sumberdaya manusia, teknik dan manajemen pemeliharaan, tantangan hama penyakit ikan dan lingkungan. Selain itu, faktor utama yang mempengaruhi kegiatan budidaya laut adalah pakan. Pakan merupakan komponen terbesar dalam kegiatan budidaya, dimana dapat mencapai $60 \%$ dari biaya produksi.

Kendala yang dihadapi sekarang ini adalah harga pakan yang terus naik dan semakin tidak terjangkau para pembudidaya ikan tradisional. Bukan hanya harga pakan pelet yang meningkat, namun harga ikan rucah (trash fish) pun semakin mahal bahkan semakin susah diperoleh: karena disamping hasil tangkapan yang sedikit, juga bersaing sebagai menu makan manusia. Berbagai upaya dilakukan untuk melakukan efisiensi dalam konsumsi pakan seperti penggunaan probiotik, hormon pertumbuhan, protein rekombinan, dan bahan feed additivelfeed supplement lainnya. Penggunaan berbagai macam bahan penambah nafsu makan atau pemacu pertumbuhan ini akan menimbulkan biaya tersendiri. Salah satu inovasi teknologi budidaya yang dapat dilakukan adalah dengan melakukan pemuasaan pada ikan budidaya secara periodik. Pemuasaan secara periodik merupakan salah satu strategi dalam manajemen pemberian pakan yang banyak dilakukan dalam usaha budidaya untuk memacu respon pertumbuhan. Menurut Yuwono, et al. (2005), ikan yang dipuasakan dapat mengalami peningkatan konsumsi pakan selama beberapa hari pada waktu diberi pakan kembali. Chatakondi and Yant (2001) melaporkan bahwa puasa selama periode tertentu, yaitu selama satu, dua atau tiga hari, kemudidan diikuti dengan pemberian pakan kembali akan menyebabkan ikan mengalami hyperphagia, yaitu periode dimana nafsu makan ikan meningkat, selama dua sampai tiga hari, kemudian menurun kembali ke nafsu makan normal.

Berbagai penelitian yang telah dilakukan pada beberapa spesies ikan menunjukkan bahwa pemuasaan menghasilkan respon positif terhadap pertumbuhan. Pemuasaan pakan terbukti menghasilkan pertumbuhan kompensasi misalnya pada ikan Lates calcarifer (Tian dan Qin, 2004), Ictalurus punctatus (Chatakondi dan Yant, 2001) dan Gasterosteus aculeatus (Zhu et al., 2003), ikan bawal air tawar Colossoma macropomum (Ekasanti et al, 2007), bawal bintang Trachinotus blochii (Hendrianto et.al, 2015). 
Pertumbuhan kompensatori atau pertumbuhan pengganti (compensatory growth) didefinisikan sebagai pertumbuhan yang lebih besar dari kondisi normal saat pemberian pakan kembali setelah mengalami masa pengurangan pakan atau pemuasaan (Purbomartono, et.al, 2009). Nikkie et.al. (2004) juga menambahkan, pertumbuhan kompensatori merujuk pada kondisi pertumbuhan cepat yang mengikuti suatu periode penurunan pertumbuhan sebagai hasil dari pembatasan ketersediaan pakan atau kondisi lingkungan yang tidak sesuai lainnya.

Pembatasan pakan baik secara tunggal maupun periodik mampu meningkatkan kecepatan pertumbuhan (compensatory growth), yang merupakan fase percepatan pertumbuhan setelah ikan diberikan pakan kembali (Rachmawati, et al., 2010).

Ikan kakap putih (Lates calcarifer, Bloch) merupakan salah satu komoditas budidaya laut yang mempunyai prospek yang bagus dan bernilai ekonomis tinggi, serta salah satu spesies yang sangat populer dibudidayakan selain ikan kerapu dan bandeng. Disamping itu di wilayah tropis dan subtropis kawasan Asia-Pasifik, kakap putih yang dikenal juga dengan nama Giant Sea Perch atau Asian Sea bass, merupakan bahan makanan asal ikan yang bernilai komersial (Mathew, 2009). Oleh karena harga yang relatif tinggi di pasaran, kakap menjadi komoditas yang menarik untuk dibudidayakan skala besar maupun kecil. Disamping itu juga menjadi salah satu ikan pancingan yang digemari.

Beberapa keunggulan ikan kakap putih adalah: warna daging putih, pemeliharaan larvanya relatif mudah dengan waktu pemeliharaan singkat, sintasan yang dihasilkan tinggi, pertumbuhan cepat, pakan yang digunakan dapat menggunakan pellet dan ikan rucah, serta dapat dibudidayakan di air laut maupun di air payau (Fermin dkk, 1996, Rimmer, 2003 dalam Lestari, 2015).

Beberapa keunggulan tersebut menyebabkan permintaan cenderung meningkat setiap tahunnya, baik ukuran benih maupun konsumsi di pasar lokal dan ekspor. Namun belakangan ini banyak kendala yang dihadapi pembudidaya dalam pemeliharaan kakap putih. Selain faktor penyakit dan kondisi kualitas perairan, pakan menjadi kendala lainnya terutama bagi pembudidaya tradisional dengan keterbatasan biaya pakan, khususnya pelet ikan laut, dimana harga pelet semakin meningkat. Selain itu manajemen pakan yang kurang baik dapat menyebabkan biaya produksi tidak berimbang dengan hasilnya.

Hasil-hasil kajian dan penelitian sebelumnya cenderung lebih banyak pada stadia benih dan skala laboratorium, tetapi belum banyak pada skala massal (lapang) hingga mencapai ukuran ikan siap panen/konsumsi. Oleh sebab itu melalui kegiatan perekayasaan ini 
diharapkan dapat menghasilkan inovasi teknologi sederhana dan aplikatif, tentang bagaimana pengaturan pemberian pakan pada kegiatan budidaya ikan kakap putih di KJA melalui pemuasaan secara periodik.

Adapun tujuan dari kegiatan ini adalah untuk mengetahui dampak pengaturan pemberian pakan melalui pemuasaan secara periodik pada pemeliharaan ikan kakap putih di KJA. Beberapa parameter pengamatan yang ingin diperoleh antara lain: pertumbuhan, tingkat kelulushidupan, tingkat konversi pakan (FCR), dan efisiensi pakan.

\section{METODOLOGI}

Kegiatan perekayasaan ini dilakukan lebih kurang selama enam bulan pada rentang bulan Februari - Agustus 2017. Kegiatan perekayasaan dilakukan di Balai Perikanan Budidaya Laut Batam Provinsi Kepulauan Riau, tepatnya di lokasi keramba jaring apung.

Bahan-bahan yang digunakan dalam kegiatan perekayasaan ini adalah ikan kakap putih berukuran tebar awal $15-16 \mathrm{~cm}(48,50-67,15$ gram) sebanyak 1.800 ekor, pakan pellet komersial, air tawar, dan acrilavin. Peralatan yang digunakan dalam kegiatan ini antara lain keramba jaring apung HDPE berukuran $4 \times 4 \mathrm{~m}$, jaring PE ukuran $4 \times 4 \times 3 \mathrm{~m}$ (messize $3 / 4$ inchi, 1 inchi dan 1,5 inchi), pemberat jaring, peralatan kerja (serok ikan, wadah pakan, ember, keranjang), peralatan sampling (timbangan, mistar, ATK, kalkulator), peralatan pengukuran kualitas air $(\mathrm{pH}$ meter, DO meter, refraktometer, kolorimeter), dan alat dokumentasi.

Sarana pemeliharaan seperti keramba jaring apung, jaring, peralatan kerja, peralatan sampling dipersiapkan sebelum ikan ditebar. Ikan uji kakap putih berasal dari kegiatan produksipenggelondongan, dimana telah dilakukan pemilahan ukuran (grading) sebelumnya untuk mendapatkan ukuran seragam. Ikan uji ditebar di dua jaring berbeda perlakuan dengan kepadatan yang sama masing-masing 900 ekor/jaring.

Pada masa pengujian dilakukan inovasi teknologi secara sederhana berupa manajemen pemberian pakan dengan pengaturan sesuai perlakuan sebagai berikut: Perlakuan A, yang mana ikan uji diberi pakan pellet komersial dengan manajemen pemuasaan secara periodik 5 1, (dimana lima hari ikan diberi pakan lalu satu hari ikan dipuasakan, demikian berulang hingga akhir pengujian); dan Perlakuan B, yang mana ikan uji diberi pakan pellet komersial setiap hari. 
Jenis pakan yang diberikan berupa pellet komersial untuk ikan kakap putih dengan kandungan protein $42 \%$. Frekuensi pemberian pakan sebanyak 3 kali sehari diawal tebar hingga berkurang menjadi 2 kali sehari, sesuai dosis harian dan ukuran ikan. Dosis pakan atau feeding rate awal sebanyak $4 \%$ dari biomass, selanjutnya menurun sampai $2 \%$ biomass ikan, disesuaikan dengan pertumbuhan ukuran ikan hingga akhir pengujian. Pengujian dilakukan selama lebih kurang 6 bulan. Masa pemeliharaan dilakukan dengan kegiatan pemberian pakan, penggantian jaring, perendaman air tawar sebagai upaya pencegahan dan pengobatan serangan parasit ikan dan sebagainya.

Parameter pengamatan yang dilakukan selama kegiatan adalah: pengukuran berat ikan, pertumbuhan mutlak ikan (berat), pertumbuhan harian, tingkat kelulushidupan benih (Survival Rate/SR), tingkat konversi pakan (feed convertion rate/FCR), dan tingkat efisiensi pakan. Sampling dilakukan dua minggu sekali serta penghitungan $S R$ dilakukan pada akhir pengujian. Pengukuran kondisi kualitas air dilakukan secara periodik dengan parameter: suhu, oksigen terlarut, salinitas, $\mathrm{pH}$, nitrit, amoniak, phosphate, serta kondisi kesehatan/penyakit ikan.

Metode pengolahan data hasil pengujian kegiatan yang digunakan untuk mengukur beberapa parameter adalah sebagai berikut (Effendie, 1997; Sih-Yang Sim, 2005; Yuwono et.al., 2005):

1. Pertumbuhan Mutlak

$$
\mathrm{W}=\mathrm{Wt}-\mathrm{Wo}
$$

Keterangan: $\quad \mathrm{W}=$ Berat mutlak $($ gram $)$

$\mathrm{Wd}=$ Pertumbuhan berat harian $(\mathrm{gram} / \mathrm{hari})$

$\mathrm{Wt}=$ Berat pada saat waktu $\mathrm{t}(\mathrm{gram})$

Wo $=$ Berat awal (gram)

$\mathrm{d}=$ waktu (hari)

\section{Pertumbuhan Rerata Harian (ADG)}

$\mathrm{Wd}=(\mathrm{Wt}-\mathrm{Wo}) / \mathrm{d}$

3. Penghitungan sintasan atau kelulushidupan (Survival Rate):

$$
\begin{array}{ll} 
& \mathrm{SR}=(\mathrm{Nt} / \mathrm{No}) \times 100 \\
\text { Keterangan: } & \mathrm{SR}=\text { Sintasan/kelulushidupan }(\%) \\
& \mathrm{No}=\text { Jumlah ikan awal (ekor) } \\
& \mathrm{Nt}=\text { Jumlah ikan akhir (ekor) }
\end{array}
$$

4. Penghitungan Rasio Konversi Pakan (Feed Convertion Rate/FCR) :

FCR = Jumlah pakan / pertambahan biomass

$\begin{array}{ll}\text { Keterangan: } & \text { biomass }(\text { gram }) \quad \text { Jumlah ikan } \mathrm{x} \text { rerata berat ikan } \\ & \text { pertambahan biomass }(\text { gram })=\text { Biomass akhir }- \text { biomass awal }\end{array}$ 
5. Konsumsi pakan harian (KPH), (Yuwono et.al, 2005)

$$
\mathrm{KPH}=\text { Jumlah total Pakan / Jumlah hari pemberian makan }
$$

6. Pertambahan bobot per hari makan (LPM), gram, (Yuwono et.al, 2005)

LPM = Total Biomass / Jumlah hari pemberian makan

7. Efisiensi Pakan, (Yuwono et.al, 2005)

$$
\mathrm{E}=\mathrm{LPM} / \mathrm{KPH}
$$

Keterangan: $\quad$ LPM $=$ Pertambahan bobot per hari makan $\mathrm{KPH}=$ Konsumsi Pakan Harian

\section{HASIL DAN PEMBAHASAN}

Pemeliharaan ikan kakap putih melalui manajemen pemberian pakan dengan dua perlakuan, yakni pemberian pellet dengan pemuasaaan periodik (5-1) (Perlakuan A) dan perlakuan pemberian pellet setiap hari (sebagai kontrol/Perlakuan B) Selama masa pemeliharaan lebih kurang enam bulan, terlihat pertumbuhan yang cukup bagus, seperti dapat dilihat pada Tabel 1.

Tabel 1. Data hasil pengujian pengaturan pemberian pakan ikan kakap putih (Lates calcarifer) di KJA.

\begin{tabular}{ccc} 
Sampling ke- & $\begin{array}{c}\text { Rata-rata Pertumbuhan Berat (gram) } \\
\text { Perlakuan A }\end{array}$ & $\begin{array}{c}\text { Perlakuan B } \\
\text { Perlan }\end{array}$ \\
\hline I & 65,95 & 50,12 \\
II & 82,78 & 85,72 \\
III & 107,03 & 129,32 \\
IV & 137,8 & 150,59 \\
V & 164,68 & 175,86 \\
VI & 199,17 & 203,65 \\
VII & 275,01 & 231,43 \\
VIII & 352,00 & 308,96 \\
IX & 413,02 & 386,50 \\
X & 452,38 & 440,75 \\
XI & 501,72 & 495,00 \\
\hline
\end{tabular}

Selama pengujian terlihat pertumbuhan yang berbeda diantara kedua perlakuan meski tidak terlalu besar. Untuk lebih jelas dapat dilihat pada Gambar 1 berikut : 


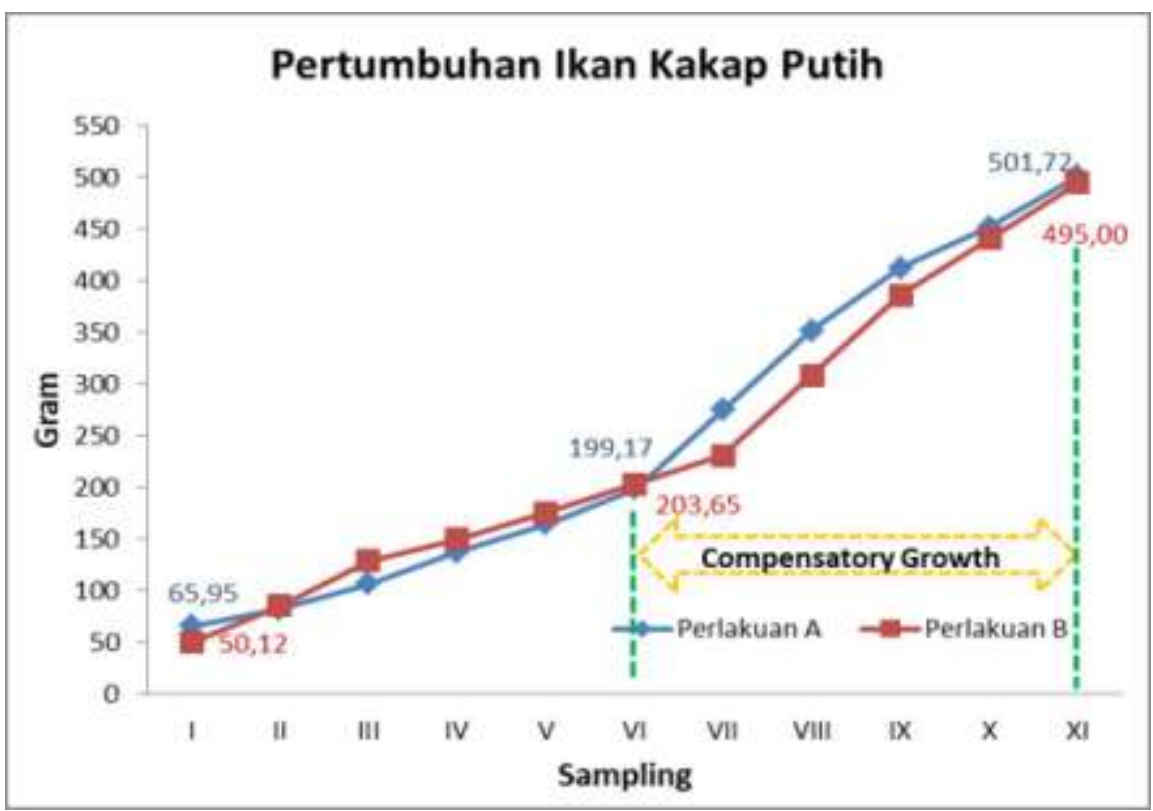

Gambar 1. Grafik pertumbuhan ikan kakap putih dengan perlakuan pemuasaan dan kontrol

Dalam kegiatan perekayasaan (applied aquaculture) ini, penerapan pengaturan pakan melalui pemuasaaan memperlihatkan adanya hal positif apabila data diatas diolah secara komprehensif, sebagaimana dapat dilihat pada Tabel 2.

Tabel 2. Hasil pengolahan data parameter pengamatan dalam pengujian pengaturan pemberian pakan ikan kakap putih (Lates calcarifer) di KJA.

\begin{tabular}{clcc}
\hline No. & \multicolumn{1}{c}{ Parameter Budidaya } & $\begin{array}{c}\text { Perlakuan A } \\
\text { (Pemuasaan 5-1) }\end{array}$ & $\begin{array}{c}\text { Perlakuan B } \\
\text { (Kontrol) }\end{array}$ \\
\hline 1 & Tebar Awal (ekor) & 900 & 900 \\
2 & Jumlah Mati (ekor) & 79 & 35 \\
3 & Jumlah Akhir (ekor) & 821 & 865 \\
4 & Survival Rate (\%) & 91,22 & 96,11 \\
5 & Pertumbuhan mutlak (gram) & 435,77 & 444,88 \\
6 & Pertumbuhan rerata harian, ADG (gram/hari) & 2,63 & 2,68 \\
7 & Jumlah hari uji (hari) & 166 & 166 \\
8 & Jumlah hari makan (hari) & 137 & 166 \\
9 & Jumlah hari puasa (hari) & 29 & 0 \\
10 & Jumlah/konsumsi pakan (gram) & 810.200 & 964.500 \\
11 & Pertambahan biomass (gram) & 352.557 & 383.067 \\
12 & Rasio konversi pakan (FCR) & 2,29 & 2,52 \\
13 & Konsumsi pakan harian (gram) & 5.914 & 5.811 \\
14 & Pertambahan bobot per hari makan (LPM) (gram) & 2.611 & 2.319 \\
15 & Efisiensi pakan & 0,44 & 0,40 \\
\hline
\end{tabular}

Dari parameter pengamatan terhadap ikan uji kakap putih seperti tertera pada Tabel 2 di atas memperlihatkan adanya variasi perbedaan yang tidak terlalu besar, tetapi memberikan 
pengaruh terhadap FCR dan efisiensi pakan. Dari parameter tingkat kelangsungan hidup, terlihat perlakuan B lebih tinggi dengan persentase SR sebesar 96,11\%, sementara perlakuan A sebesar 91,22\%. Pengamatan visual terhadap ikan uji, diduga pakan yang diberikan tidak berpengaruh besar pada tingkat kelulushidupan. Sintasan ikan uji kedua perlakuan mulai tebar hingga ukuran panen atau konsumsi tergolong sangat tinggi. Salah satu faktor yang diduga cukup berpengaruh, adalah adanya treatment perendaman rutin dengan air tawar minimal seminggu sekali di awal tebar. Selanjutnya dilihat kondisi kesehatan ikan dan biasanya ikan dengan ukuran > 200 gram dapat dilakukan perendaman sekali dalam dua minggu. Hal ini dilakukan untuk pengendalian penyakit parasit, khususnya skin fluke jenis Benedenia sp yang banyak terdapat di perairan KJA dan sering meng-infeksi ikan budidaya.

Untuk pertumbuhan mutlak, Perlakuan B memiliki nilai lebih tinggi, dengan nilai 444,88 gram; sedangkan Perlakuan A adalah sebesar 435,77 gram; ada selisih pertumbuhan 9,11 gram antara kedua perlakuan. Hal yang sama juga terjadi pada parameter pertumbuhan rerata harian (ADG), Perlakuan B memiliki nilai lebih tinggi, yaitu sebesar 2,68 gram/hari; sedangkan Perlakuan A adalah sebesar 2,63 gram/hari; terdapat selisih yang tidak besar yakni 0,05 gram/hari.

Namun demikian, dari grafik pertumbuhan di atas dapat dilihat bahwa ikan dengan pemuasaan (Perlakuan A) saat awal pengujian hingga sampling VI (dua setengah bulan pemeliharaan), pertumbuhannya lebih kecil dibanding ikan kontrol (Perlakuan B). Pada saat itu, rata-rata bobot ikan Perlakuan A adalah 199,17 gram, sedangkan Perlakuan B sudah mencapai 203,65 gram. Namun data yang diolah per sampling, menunjukkan ADG Perlakuan A lebih besar bila dibandingkan dengan Perlakuan B, yakni 2,46 berbanding 1,99.

Pengamatan pertumbuhan selanjutnya (yaitu hingga akhir pengujian), memperlihatkan bahwa ikan Perlakuan A lebih cepat dibanding ikan Perlakuan B. Data ini menunjukkan adanya pertumbuhan kompensatori pada ikan kakap putih yang dipuasakan, dimana ikan yang dipuasakan mempunyai metabolisme yang lebih baik untuk meningkatkan laju pertumbuhan setelah dilakukan pemuasaan. Dari yang semula bisa mengejar pertumbuhan ikan kontrol yang diberi pakan setiap hari hingga berhasil melampaui, sebagaimana dapat dilihat pada Gambar 1.

Hasil ini sejalan dengan yang dikatakan Purbomartono et.al. (2009), pertumbuhan yang lebih besar dari kondisi normal saat pemberian pakan kembali setelah mengalami masa pengurangan pakan atau pemuasaan dapat didefinsikan sebagai pertumbuhan kompensatori 
atau pertumbuhan pengganti (compensatory growth). Rachmawati, et al.(2010) juga mengungkapkan bahwa pembatasan pakan (baik secara tunggal maupun), mampu meningkatkan kecepatan pertumbuhan (compensatory growth), yang merupakan fase percepatan pertumbuhan setelah ikan diberikan pakan kembali.

Parameter rasio konversi pakan (FCR) menunjukkan bahwa FCR Perlakuan A lebih rendah dibanding dengan FCR Perlakuan B, yakni 2,29 berbanding 2,52. Nilai FCR yang semakin rendah menunjukkan hal yang lebih baik dari sisi biaya produksi. Sehingga dapat disimpulkan nilai FCR Perlakuan A lebih bagus dibanding Perlakuan B. Perlakuan pemuasaan secara periodik 5-1 diduga kuat dapat memperbaiki metabolisme ikan sehingga pakan yang dikonsumsi bisa lebih efektif diserap meski jumlah pakan yang diberikan lebih sedikit.

Konsumsi pakan selama pengujian memperlihatkan Perlakuan A dengan jumlah pakan total sebesar 810.200 gram $(810,2 \mathrm{~kg})$, lebih sedikit dibanding ikan pada Perlakuan B yang mengkonsumsi pellet sebanyak 964.500 gram $(964,5 \mathrm{~kg})$. Ada selisih 154.300 gram $(154,3$ kg) pakan diantara kedua perlakuan. Namun demikian, konsumsi pakan yang lebih banyak tidak diikuti pertambahan bobot yang jauh lebih tinggi, dapat dilihat pada pertumbuhan mutlak kedua perlakuan yang hanya selisih 9,11 gram, dimana perlakuan B 444,88 gram berbanding 435,77 gram di perlakuan A.

Adapun sedikitnya jumlah pakan Perlakuan A dinilai wajar, sebab selama pengujian ada jeda waktu ikan uji Perlakuan A berpuasa satu setelah lima hari sebelumnya diberi makan. Selama 166 hari pengujian, total 29 hari ikan perlakuan A tidak diberi makan sedangkan jumlah hari makannya 137 hari. Bila dibanding Perlakuan B yang 166 hari penuh, hal ini sangat menghemat jumlah pakan.

Demikian pula dengan konsumsi pakan harian, dimana Perlakuan A jumlah pakan yang dikonsumsi rerata 5.914 gram/hari, berbanding 5.811 gram/hari pada Perlakuan B, dengan selisih yang tidak terlalu besar yakni 103 gram. Namun demikian, hitungan hari yang dipakai dalam hal ini adalah hari diberi makan; dimana Perlakuan A selama 137 hari, sedangkan Perlakuan B 166 hari. Sementara parameter pertambahan bobot per hari makan (LPM) menunjukkan Perlakuan A sebanyak 2.539 gram, lebih besar daripada Perlakuan B yang 2.319 gram. Ternyata berkurangnya pakan yang diberikan ke ikan uji Perlakuan A tidak menurunkan pertumbuhan, sebagaimana dikatakan Yuwono et.al. (2005).

Prinsip dalam pemuasaan adalah pemberian makan seminimal mungkin dan pertumbuhannya tidak terhambat (Goddart, 1996). Pembudidayaan ikan dengan pemuasaan 
(fasting) pada periode waktu tertentu kemudian diikuti pemberian pakan yang cukup atau satiation level (Stangrres et at, 2000). Kondisi ini dilakukan agar terjadi pertumbuhan yang cepat (compensatory growth) pada periode pemberian pakan (satiation level) setelah periode pemuasaan (fasting) (Santoso, et al, 2006).

Dari data konsumsi pakan harian dan pertambahan bobot per hari dapat dihitung tingkat efisiensi pakan. Adapun nilai efisiensi pakan menunjukkan Perlakuan A memiliki efisiensi pakan yang lebih tinggi yaitu sebesar 0,44, dibanding perlakuan B sebesar 0,40. Hal ini sejalan dengan beberapa hasil penelitian lainnya. Menurut Chatakondi dan Yant (2001), efisiensi pakan meningkat setelah ikan mengalami daur ulang puasa 1 hari atau bahkan 3 hari diikuti pemberian pakan kembali. Namun efisiensi pakan dapat menurun jika ikan dipuasakan lebih dari 3 hari kemudian diberi makan kembali selama hyperphagia, sebagaimana dilaporkan pada ikan Ictalurus punctatus (Gaylord et.al.,2001)

$\mathrm{Wu}$, et. al. (2011) dalam Yuwono, et al. (2005) mengatakan efisiensi pakan terjadi pada ikan yang mengalami pertumbuhan kompensasi, yaitu ikan mengalami pertumbuhan yang cepat saat diberi pakan kembali setelah dipuasakan selama periode tertentu. Menurut Santoso, et al (2006) hal inilah yang mengakibatkan tidak ada perbedaan atau relatif kecil perbedaan tingkat pertumbuhan ikan yang diberi pakan setiap hari dan yang dipuasakan atau dibatasi pemberian pakannya. Lebih lanjut menurut Roa dan Vincente (2009) umumnya ikan menunjukkan konsumsi pakan yang berlebihan pada saat pemberian pakan kembali. Selain itu juga menunjukkan pengeluaran metabolik yang rendah saat dipuasakan, sehingga dengan tingginya tingkat konsumsi pakan saat pemberian pakan kembali akan mengakibatkan tingginya jumlah nutrisi yang tersedia untuk pertumbuhan.

Ikan yang dipuasakan dapat mengalami peningkatan konsumsi pakan selama beberapa hari pada waktu diberi makan kembali. Chatakondi dan Yant (2001) melaporkan bahwa puasa selama periode tertentu, yaitu selama satu, dua atau tiga hari, kemudidan diikuti dengan pemberian pakan kembali akan menyebabkan ikan mengalami hyperphagia, yaitu periode dimana nafsu makan ikan meningkat, selama dua sampai tiga hari, kemudian menurun kembali ke nafsu makan normal. Peningkatan konsumsi pakan setelah ikan dipuasakan tersebut diikuti peningkatan laju pertumbuhan mutlak, sehingga penggunaan pakan lebih efisien. Dalam penelitiannya pada ikan lele kanal Ictalurus punctatus, Chatakondi dan Yant (2001) menghasilkan konsumsi pakan harian meningkat pada saat ikan diberi makan kembali setelah dipuasakan (hyperpagia). 
Berbagai penelitian yang telah dilakukan pada beberapa spesies ikan menunjukkan bahwa pemuasaan menghasilkan respon positif terhadap pertumbuhan. Pemuasaan pakan terbukti menghasilkan pertumbuhan kompensasi misalnya pada ikan Lates calcarifer (Tian dan Qin, 2004), Ictalurus punctatus (Chatakondi dan Yant, 2001), Gasterosteus aculeatus (Zhu et al., 2003), ikan bawal air tawar (Colossoma macropomum) (Ekasanti et al, 2007), dan ikan kerapu bebek (Yuwono et al, 2005).

Diduga pengurangan pemberian pakan pada ikan kakap putih dengan cara dipuasakan dapat meningkatkan efisiensi pakan tanpa memperburuk pertumbuhan, tetapi meningkatkan laju pertumbuhan mutlak. Sebagaimana dikatakan Yuwono (2005), yang melakukan penelitian pada ikan kerapu bebek, bahwa ikan kerapu bebek mengalami pertumbuhan yang pesat setelah dipuasakan karena konsumsi pakan harian yang meningkat. Peningkatan konsumsi pakan memberikan pasokan nutrisi yang cukup untuk memenuhi kebutuhan metabolisme yang meningkatkan pada periode pertumbuhan yang cepat.

Dalam penelitiannya, Gaylord et.al (2001), melakukan pemuasaan secara periodik pada ikan lele Ictalurus punctatus yang menunjukkan peningkatan laju pertumbuhan disebabkan oleh meningkatnya konsentrasi trioksin dan triiodotironin dalam plasma darah ikan pada saat diberi pakan kembali setelah dipuasakan. Hormon tiroid dimungkin berperan dalam memacu pertumbuhan (Yuwono et al., 2005).

Dalam pengamatan terhadap ikan kakap putih yang dipuasakan satu hari sebelumnya terlihat ikan uji mengalami peningkatan konsumsi pakan dibanding hari normal. Ikan kakap putih tampak lebih agresif menyambar pakan pellet yang diberikan. Hal ini lazim terjadi secara alamiah dengan dampak yang bagus. Sebagaimana dikatakan Chatakondi dan Yant (2001), aplikasi kondisi fenomena biologis yang terjadi secara alami ini dapat meningkatkan pertumbuhan dan sintasan, mengurangi periode masa pemeliharaan, dan selanjutnya mengurangi biaya produksi.

Pakan merupakan komponen terbesar dalam biaya produksi kegiatan budidaya, bahkan dapat mencapai 60\% (Yuwono et.al., 2005). Oleh sebab itu secara ekonomis perhitungan biaya pakan perlu dilakukan. Dalam kegiatan ini, perbedaan total konsumsi pakan antara Perlakuan A dan Perlakuan B memberikan dampak yang cukup besar terhadap biaya produksi. Pakan yang digunakan adalah pelet komersial untuk ikan kakap dengan kandungan protein $42 \%$, dengan penggunaan dari awal hingga akhir pengujian menggunakan pelet berurutan ukuran $5 \mathrm{~mm}, 7 \mathrm{~mm}$, dan $10 \mathrm{~mm}$. Apabila dikalkulasi biaya pakan selama 
pengujian, dengan harga sama yakni Rp. 19.000/ kg (data wawancara dengan pedagang lokal Batam, harga tahun 2017), Perlakuan A dengan total jumlah pakan sebanyak 810,2 kg maka biaya yang dikeluarkan sebesar Rp.15.393.800. Sementara perlakuan B dengan konsumsi pelet 964,5 kg menyerap biaya sebesar Rp.18.325.500. Sehingga dengan pemuasaan terdapat penghematan pakan sebanyak 154,3 kg atau 15,99\% dengan nilai sebesar Rp.2.931.700.

Sementara itu data kualitas air di keramba jaring apung selama kegiatan sebagai berikut: $\mathrm{pH}$ berkisar 7,5 -7,85, salinitas $29-30 \%$ o oksigen terlarut 5,4-6,3 ppm, suhu 28,5 $-30,8{ }^{\circ} \mathrm{C}$, nitrit $0 \mathrm{ppm}$, nitrat $0 \mathrm{ppm}$, amonia $0-0,01 \mathrm{ppm}$, dan fosfat $0-0,01 \mathrm{ppm}$. Dari hasil pengukuran parameter kualitas air terlihat, kondisi air pemeliharaan masih dalam kisaran yang mendukung bagi kegiatan budidaya, sesuai rujukan baku mutu Keputusan Menteri Lingkungan Hidup No. 51 Th 2004 tentang Baku Mutu Air Laut, Lampiran 3 (baku mutu air laut untuk biota laut).

Terkait suhu perairan, dimana menjelang akhir pengujian suhu perairan di KJA sedikit menurun, sehingga diduga berpengaruh terhadap nafsu makan ikan uji di kedua perlakuan. Diketahui bahwa suhu perairan merupakan salah satu faktor yang mempengaruhi nafsu makan ikan, pada suhu yang lebih dingin nafsu makan ikan cenderung menurun. Kondisi ini terjadi pada kedua perlakuan. Dampaknya jumlah pakan harian yang disiapkan sesuai dosis pemberian pakan harian menjadi menurun.

\section{KESIMPULAN}

Ikan kakap putih yang dipelihara di keramba jaring apung dengan pengaturan pemberian pakan melalui pemuasaan secara periodik 5 hari makan dan 1 hari puasa (Perlakuan A) mempunyai rasio konversi pakan, konsumsi pakan harian, pertambahan bobot per hari makan serta efisiensi pakan yang lebih baik dibanding ikan dengan pemberian pakan setiap hari (Perlakuan B). Sebaliknya perlakuan B lebih unggul dari sisi pertumbuhan mutlak dan pertumbuhan rerata harian. Namun meski tingkat kelulushidupan lebih tinggi dibanding Perlakuan A, diduga faktor pengaturan pemberian pakan tidak berpengaruh terhadap sintasan. Demikian juga dengan jumlah total konsumsi pakan dimana Perlakuan B lebih banyak dibanding Perlakuan A, tetapi dari sisi biaya tidak ekonomis. Pemuasaan secara periodik 5-1 dapat menjadi salah satu solusi untuk efisiensi kegiatan budidaya ikan kakap putih. 


\section{REFERENSI}

Chatakondi, N.G. and R.D. Yant. 2001. Application of compensatory growth to enhance production in channel catfish Ictalurus punctatus. Journal of the World Aquaculture Society, 32 (3): 278-285.

Effendie MI. 1997. Biologi Perikanan. Yayasan Pustaka Nusatama. Yogyakarta.

Ekasanti, A., P. Sukardi dan E. Yuwono. 2007. Pertumbuhan ikan bawal air tawar (Colossoma macropomum) yang dipuasakan secara periodik. Jurnal Aquacultura Indonesiana (2007) 8 (3) : 183-188

Gaylord, TG, McKenzie DS, and Gatlin III DM.2001. Growth performance, body composition and plasma thyroid of hormone status of channel catfish (Ictalurus punctatus) in response of short-therm feed deprivation and refeeding. Fish Physiology and Biochemistry 24 (1): 73-79.

Goddart, S. 1996. Feed Management and Intensive Aquaculture. New York: Chapman and Hall.

Lestari,A.S. 2015. Pengaturan periode makan pada pembesaran ikan kakap putih (Lates Calcarifer, Bloch) di keramba jaring apung. Tehnical Note. BPBL Batam.

Mathew Grace. 2009. Taxonomy, identification and biology of seabass (Lates calcarifer). National Training on Cage Culture of Seabass held at CMFRI, Kochi, $14-23$ December 2009. Central Marine Fisheries Research Institute, India.

Purbomartono, C., Hartoyo \& A. Kurniawan. 2009. Pertumbuhan kompensasi pada ikan nila merah (Oreochromis niloticus) dengan interval waktu pemuasaan yang berbeda. Journal of Fisheries Sciences: 11(1): 19-24.

Rachmawati F. N., U. Susilo \& Y. Sistina. 2010. Respon fisiologi ikan nila, Oreochromis niloticus, yang distimulasi dengan daur pemuasaan dan pemberian pakan kembali. Seminar Nasional Biologi 2010. Fakultas Biologi UGM, Yogyakarta 24-25 September 2010.

Roa R.L. \& Vincente, H. J. 2009. Compensatory weight gain and muscle tissue biochemical composition of gift tilapia (Oreocromis niloticus) juveniles. Journal of Environment And Aquatic Resources: 11(1):99-111.

Santoso, A. Sarjito \& A. Djunaedi. 2006. Fenomena pertumbuhan kompensatori dan kualitas ikan nila merah (Oreochromis sp.) pada kondisi laut. Jurnal llmu Kelautan: 11(2):106-111.

Sih-Yang Sim, Rimmer M, Williams K, Toledo, JD, Sugama, K, Rumengan I and Phillips MJ. 2005. Pedoman praktis pemberian dan pengelolaan pakan untuk kerapu yang dibudidaya. NACA-ACIAR-DKP-SEAFDEC-CSIRO. 18 Hal. 
Tian, X. and J.G. Qin. 2004. Effect of previous ration restriction on ompensatory growth in Barramundi Lates calcarifer. Aquaculture, 235: 273-283.

Yuwono, E. P. Sukardi, I.Sulistyo. 2005. Konsumsi dan efisiensi pakan pada ikan kerapu bebek (Cromileptes altivelis) yang dipuasakan secara periodik. Jurnal Berkala Penelitian Hayati : 10 (129-132).

Zhu, X., L. Wu, Y. Cui, Y. Yang and R.J. Wootton. 2003. Compensatory growth response in three- spinned Stickleback in relation to feed deprivation protocols. Journal of Fish Biology, 62: 195-205. 